\title{
SOME MULTI-COUNTRY EVIDENCE ON THE EFFECTS OF REAL EXCHANGE RATES ON OUTPUT
}

by

Steven B. Kamin and Marc Klau

September 1997

BANK FOR INTERNATIONAL SETTLEMENTS

Monetary and Economic Department

BASLE 
BIS Working Papers are written by members of the Monetary and Economic Department of the Bank for International Settlements, and from time to time by other economists, and are published by the Bank. The papers are on subjects of topical interest and are technical in character. The views expressed in them are those of their authors and not necessarily the views of the BIS.

(C) Bank for International Settlements 1997

CH-4002 Basle, Switzerland

Also available on the BIS World Wide Web site (http://www.bis.org).

All rights reserved. Brief excerpts may be reproduced or translated provided the source is stated.

ISSN 1020-0959 


\title{
SOME MULTI-COUNTRY EVIDENCE ON THE EFFECTS OF REAL EXCHANGE RATES ON OUTPUT *
}

by

\author{
Steven B. Kamin and Marc Klau
}

September 1997

\begin{abstract}
A considerable amount of theoretical literature suggests that, contrary to the predictions of textbook analysis, exchange rate devaluations may be contractionary rather than expansionary. This hypothesis has also received considerable empirical support. However, prior statistical analyses of the effects of exchange rate devaluation on output have been subject to several limitations: (i) they have failed to distinguish adequately between short and long-run effects; (ii) they have not controlled for the full range of external shocks; and (iii) they have not considered whether the effects of devaluation might differ between different regions of the world. The purpose of this paper is to estimate the impact of devaluation on output for 27 countries while attempting to address these limitations in previous empirical analyses. We find no evidence that devaluations are contractionary in the long run. Additionally, controlling for sources of spurious correlation and reverse causality appears to mute the measured contractionary effect of devaluation in the short run, although evidence that this effect exists remains even after these controls are introduced. Finally, no significant differences among the regions stand out; in fact, while the literature on contractionary devaluation has focused primarily on developing countries, we found no evidence that this effect is stronger in developing countries than in industrialised countries.
\end{abstract}

\footnotetext{
We wish to thank Palle Andersen, Joseph Bisignano, Frank Smets, Stefan Gerlach, Elmar Koch, Kostas Tsatsaronis and Philip Turner for useful advice and suggestions.
} 



\section{Contents}

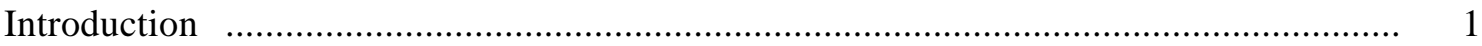

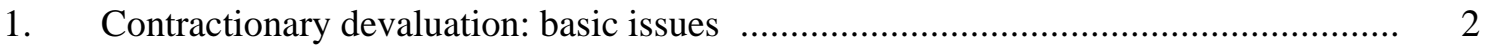

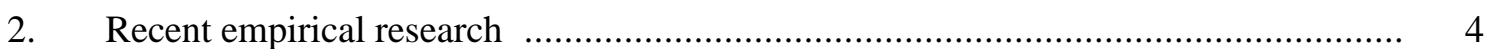



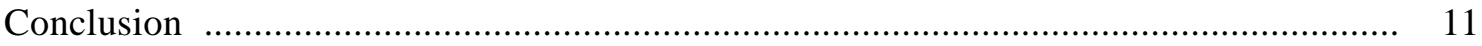

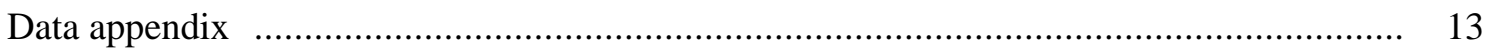

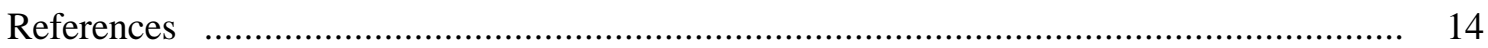





\section{Introduction}

The financial crisis that followed Mexico's devaluation of the peso in 1994 reinforced scepticism concerning the benefits of fixing the nominal exchange rate and raised interest among developing countries in more flexible exchange rate regimes. Fixed exchange rate experiments have been criticised, among other reasons, because they have encouraged real appreciations that may have restrained growth. In the view of such critics (see Dornbusch and Werner (1994)), policies geared towards keeping the real exchange rate competitive not only help prevent balance-of-payments crises, but also encourage output growth. The belief that a competitive exchange rate encourages exports and hence growth is a fundamental tenet of the conventional wisdom of macroeconomic management.

However, many developing countries have tended to resist devaluation, partly because of concerns that such a policy would be contractionary, not expansionary. This view derives from the experience of countries such as Mexico, where, as indicated in Chart 1, real depreciations (declines) of the peso have consistently been associated with declines in output, while real appreciations (increases) have been linked to expansions. The possibility that devaluations are contractionary has received considerable theoretical attention (see, among others, Diaz-Alejandro (1963), Krugman and Taylor (1978) and Lizondo and Montiel (1989)). As discussed further below, many empirical analyses, both multi-country panel regressions and models applied to individual countries, also support the hypothesis that devaluation leads to contraction rather than expansion.

If devaluations are genuinely contractionary, this may pose a dilemma to policy-makers seeking to achieve simultaneously both high output growth and a strong balance-of-payments position. However, most of the prior empirical analyses that support the contractionary devaluation hypothesis are subject to important limitations. First, most analyses have not clearly distinguished between short and long-run effects; devaluations may exert a transitional contractionary influence that gives way to an expansionary effect in the longer run. Second, many previous studies do not control adequately for shocks that might simultaneously induce devaluation and economic contraction, leading to a spurious correlation between the two.

Finally, previous studies do not provide a sense of how universal the contractionary devaluation effect may be. Most case studies of contractionary devaluation have focused on Latin American countries, where resistance to devaluation has been most pronounced. Conversely, many Asian countries have kept their exchange rates competitive in order to stimulate export-led growth. The question therefore arises as to whether the reason exchange rate policies have differed in the two regions is that devaluation is contractionary in Latin America and expansionary or neutral in Asia.

Additionally, previous studies have not considered whether devaluations might be contractionary in developed countries. The literature on contractionary devaluation has generally focused on developing countries, with the implicit assumption that the effects of devaluation in 
industrialised countries are more likely to adhere to the conventional textbook model. However, many of the factors underlying contractionary devaluation (see below) are present in developed as well as developing countries.

The purpose of this paper is to address some of the limitations discussed above in order to provide a more complete and compelling test of the hypothesis that devaluations are contractionary, and in order to distinguish both short and long-run effects and effects in different regions of the world. To that end, an equation linking output to the real exchange rate for a group of 27 countries - eight Latin American, six Asian and 13 industrialised - is estimated. The analysis extends previous research in several ways. First, an error-correction specification is adopted that allows the long and short-run impacts of exchange rates on output to be more clearly distinguished than in previous panel regressions. Second, the regressions better control for exogenous shocks - to the terms of trade, world interest rates, industrial country growth or the capital account - that might lead to spurious correlation between output and the real exchange rate. Finally, the research compares the response of output to real exchange rates in the three regions - Latin America, Asia and the industrialised countries.

Section 1 below addresses various explanations for the often observed association of devaluation and economic contraction, while Section 2 describes previous research on the effects of devaluation on output. In Section 3, panel data regressions for Latin America, Asia and the industrialised countries are presented and compared. The final section concludes.

\section{Contractionary devaluation: basic issues}

The tight correlation between the Mexican real exchange rate and real GDP in Chart 1, suggesting that devaluations are contractionary and appreciations are expansionary, may result from a number of factors. First, it may reflect the spurious correlation of both the exchange rate and GDP with some third factor. A downturn in the terms of trade, a reversal of capital inflows or a decline in industrial country GDP may simultaneously force the authorities to devalue and cause economic activity to decline, even if no direct connection between exchange rates and GDP exists. Similarly, a loosening of fiscal policy might both appreciate the real exchange rate and stimulate economic activity, again with no direct linkage between the latter two variables.

Second, causality may run from output to the real exchange rate rather than vice versa. A large literature, focusing on the real appreciation that typically accompanies fixed exchange rate strategies, ${ }^{1}$ suggests that the expansion of aggregate demand resulting from inflation stabilisation pushes up the prices of non-traded goods - while tradable prices are fixed by the pegged exchange rate

1 See Kiguel and Liviatan (1992), Calvo and Vegh (1993), Uribe (1995), Roldos (1995), Mendoza and Uribe (1996) and Kamin (1996). 
- thereby causing the real exchange rate to appreciate. This, also, could lead to the positive correlation between real exchange rates and output shown in Chart 1.

Chart 1

\section{Real effective exchange rate and real GDP in Mexico ${ }^{1}$}



Note: An increase in the real effective exchange rate indicates an appreciation.

${ }^{1} 1990=100 . \quad{ }^{2}$ In terms of relative consumer prices. $\quad{ }^{3}$ Seasonally adjusted.

Finally, the evidence shown in Chart 1 could reflect a genuine contractionary effect of devaluation on output. In the conventional textbook model, devaluation is generally characterised as being expansionary because it encourages the production of tradable goods. ${ }^{2}$ However, as shown by Diaz-Alejandro (1963), Krugman and Taylor (1978) and others, this positive effect could be offset by contractionary impacts in the non-tradable sector.

Because, in the long run, nominal devaluations are believed to lead to proportionate increases in prices that leave real exchange rates and economic activity unchanged, analyses of the effects of devaluation on output have usually been confined themselves to short-run effects (see Lizondo and Montiel (1989)). Contractionary effects are usually modelled as temporary, the outcome of explicitly transitional processes following a single nominal devaluation. For example, devaluation may lead to immediate increases in prices, but because it takes time for nominal wages or the money supply to catch up, real wages and/or real balances decline temporarily and reduce aggregate demand (Diaz-Alejandro (1963), Krugman and Taylor (1978)). Alternatively, devaluation may lead to contractionary increases in the real value of trade deficits (Krugman and Taylor (1978)) or of foreign indebtedness (Lizondo and Montiel (1989)) until trade and balance-sheet adjustments take place. Finally, until price increases return the real exchange rate to its equilibrium level, higher levels of inflation may depress deposits, loanable funds and hence bank credit (Copelman and Werner (1996)).

2 The literature on the macroeconomic effects of devaluation in industrial countries is too voluminous to summarise here. See Dornbusch (1980) for a survey of relevant models. 
In contrast, the theoretical literature on contractionary devaluation has not addressed closely the impact of a permanent real devaluation, that is, of (possibly) continuous depreciation of the nominal exchange rate in order to keep the real exchange rate more depreciated than its initial or equilibrium level. On the one hand, a permanent real devaluation might be expansionary, even if impact effects are contractionary, since more time is provided for tradable production to respond fully to improved incentives. On the other hand, keeping the real exchange rate persistently devalued may lead to a permanently higher level of inflation, as shown in Kamin (1996) and Calvo, Reinhart and Vegh (1994), that has persistent negative effects on output.

\section{Recent empirical research}

Multi-country studies. In a pooled time-series/cross-country sample, Edwards (1989) regresses real GDP for 12 developing countries on the nominal and real exchange rate, government spending, the terms of trade and measures of money growth. He finds that even holding other factors constant, devaluations tended to reduce output in the short run; his results for the long-run effect of a real devaluation were more mixed, but on balance suggested that the initial contractionary effect was not reversed subsequently.

Agenor (1991) uses a pooled sample of 23 developing countries to regress output growth on contemporaneous and lagged levels of the real exchange rate and on deviations of actual from expected changes in the real exchange rate, government spending, the money supply and foreign income. He finds that surprises in real exchange rate depreciation actually boost output growth, but that depreciations of the level of the real exchange rate have a contractionary effect that is not subsequently reversed.

Finally, Morley (1992) analyses the effect of real exchange rates on output during 28 devaluations in developing countries, holding constant the terms of trade, import growth, the money supply and the fiscal balance. He finds that depreciations of the level of the real exchange rate reduce output over a period of two years, but does not test to see whether this effect is subsequently reversed.

Findings from VAR models. The expanding application of VAR models to developing countries, while not focused on the effects of exchange rates on output per se, has yielded relevant information. Rogers and Wang (1995), Santaella and Vela (1996), Copelman and Werner (1996) and Kamin and Rogers (1997) estimate VAR models for Mexico, and all find that depreciation shocks to some measure of the exchange rate (real or nominal, levels or rates of change) lead to declines in output. Rodriguez and Diaz (1995) reach similar results in a VAR for Peru, as do Hoffmaister and Vegh (1996) for Uruguay. Hence, the findings of VAR analysis applied to individual countries have been consistent with the findings of contractionary devaluation obtained from panel data estimations.

Limitations of previous research. Notwithstanding the consistency of their findings, the studies surveyed above are subject to several limitations. First, few of the studies adequately control 
for the full range of external shocks that might simultaneously induce devaluation and economic contraction. In particular, few of the studies control for reversals of the capital account, which have been an important factor in Latin American devaluations of the 1980s and 1990s. ${ }^{3}$

Second, few of the studies distinguish clearly enough between short and long-run effects of a real devaluation. In the panel regression studies, tests of the long-run effect have been implemented by summing coefficients on a few lags of the exchange rate (Edwards (1989), Agenor (1991)); however, this may not be adequate if the lags in the effects of exchange rate changes are quite long, as suggested by Morley (1992). In many of the VAR studies, it is difficult to interpret whether shocks represent short or long-term effects - for example, it is not clear how shocks to the rate of depreciation relate to shocks to the level of the real exchange rate. Hence, the studies do not fully address the long-term impact of a sustained real devaluation.

Finally, prior studies do not determine whether contractionary devaluation holds equally in different regions. The VAR studies cited above are all for single countries in Latin America, while the panel data studies do not subdivide their samples and compare results.

\section{Panel regression estimates}

The equation below represents the most basic model estimated in this study. Because there is a multiplicity of different theories and factors underlying the contractionary devaluation hypothesis, the equation is not derived from a particular theoretical model, but is designed to be sufficiently general to test different variants of that hypothesis. In essence, the equation is an errorcorrection model for output, based on the assumption that output is cointegrated with potential output, so that the output gap represents the error in the cointegrating vector. Changes in output are induced by non-zero levels of the output gap, as reflected in the coefficient $\beta 4$. Positive gaps are expected to depress output, causing $\beta 4$ to be negative. As is conventional in error-correction equations, additional dynamics in the reaction of output growth to shocks are accounted for by the coefficient on lagged output growth, $\beta 3$.

The additional contribution of the real exchange rate to output, if it exists, is measured in two ways. First, changes in the real exchange rate may have temporary impact effects on output that dissipate over the longer term, so that the steady-state level of output is unchanged. This temporary, contemporaneous impact of exchange rate changes on output will be reflected in $\beta 1$. Second, to the extent that the level of the real exchange rate exerts a longer-term effect on output, this is reflected in $\beta 2$.

3 Kamin and Rogers (1997) is an exception. They find capital account shocks to be an important determinant of Mexican GDP; even so, devaluation shocks also depress output. 


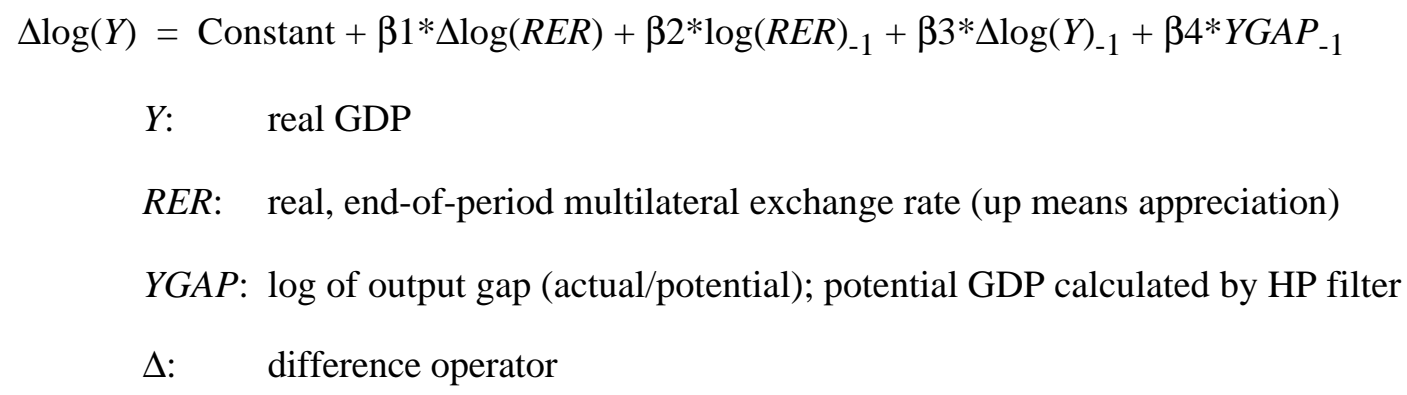

The dataset for the statistical analysis consists of pooled annual data from 27 countries, listed in Table 1, for the period 1970-96, depending on data availability. ${ }^{4}$ The choice of countries in the three regions - Latin America, Asia and the industrialised world - was determined primarily by the availability of data, both for the basic variables shown in equation (1) and for the control variables introduced in subsequent regressions. Additionally, the G-3 countries - Germany, Japan and the United States - were deleted from the list of industrialised countries; their economies are large enough to influence many of the external control variables introduced below, and hence leaving them in the dataset would complicate interpretation of the estimation results.

Finally, the equations were estimated using a "fixed effects" methodology. This allows the intercept term to be estimated separately for each country, thereby abstracting from country differences in long-term growth performance, even as slope coefficients are constrained to be the same across countries.

OLS estimates without controls. Table 1 presents estimation results for equation (1), both for the entire pool of 27 countries and for the three regional subsamples. As expected, in all four of the regressions the coefficient on the output gap is negative and significant. ${ }^{5}$ The coefficients on lagged GDP growth are also significant and of roughly the same magnitude in the different regions.

Turning to the real exchange rate, in all four regressions the coefficient on the contemporaneous change in the real exchange rate is positive and either significant or nearly so, indicating that appreciations of the real exchange rate raise output growth, and depreciations lower output growth. Hence, these results provide further support for the view that devaluations are, at least in the short run, contractionary.

By contrast, the coefficients on the lagged level of the real exchange rate are negative in three of the four equations, suggesting that, in the longer run, real appreciations lower economic activity and real devaluations increase it. This is entirely consistent with the textbook characterisation of the effects of devaluation. Because the negative coefficients are statistically insignificant and very small in magnitude as well, they do not provide strong support for the view that devaluations are

\footnotetext{
4 For most of the developing countries in the sample, the data do not start until 1980 or later.

5 In fact, this result is predetermined by the manner in which the HP filter calculates trend GDP.
} 
Table 1

\section{Fixed effects panel regressions - OLS, no controls}

Dependent variable: $\Delta \log (Y)$

\begin{tabular}{|l|c|c|c|c|}
\hline & All countries & Latin America & Asia & Industrialised \\
\hline$\Delta \log (R E R)$ & 0.057 & 0.069 & 0.054 & 0.037 \\
& $(5.83)$ & $(4.03)$ & $(2.16)$ & $(1.93)$ \\
$\log (R E R)_{-1}$ & -0.000 & -0.005 & -0.008 & 0.021 \\
& $(-0.07)$ & $(-0.40)$ & $(-0.79)$ & $(1.40)$ \\
$\Delta \log (Y)_{-1}$ & 0.47 & 0.39 & 0.48 & 0.59 \\
$Y G A P_{-1}$ & $(12.15)$ & $(4.60)$ & $(5.52)$ & $(10.94)$ \\
& -0.46 & -0.45 & -0.37 & -0.46 \\
& $(-13.22)$ & $(-5.77)$ & $(-5.33)$ & $(-9.89)$ \\
\hline
\end{tabular}

Asia: $\quad$ India, Indonesia, Korea, the Philippines, Taiwan and Thailand.

Latin America: $\quad$ Bolivia, Brazil, Chile, Colombia, Ecuador, Mexico, Uruguay and Venezuela.

Industrialised: Australia, Canada, Denmark, Finland, France, Greece, Iceland, Ireland, Italy, Portugal, Spain, Sweden and the United Kingdom.

Note: t-statistics in parentheses.

expansionary in the long run. At a minimum, however, these results contradict the view that devaluation has contractionary effects in the long run as well as in the short run.

Finally, the results shown in Table 1 lend some very weak support to the possibility that, in the short run, devaluations are more contractionary in Latin America than in Asia or the industrialised countries. This might, in principle, help to explain why Latin American countries have been more reluctant than Asian countries to keep their exchange rates competitive. However, given the lack of precision with which these coefficients are estimated, distinctions between the regions should probably not be overemphasised.

OLS estimates with controls. While the above results appear to support the contractionary short-run effect of devaluation, this finding could, as discussed in Section 1, reflect the correlation with devaluation of external shocks omitted from the equation. Table 2 indicates the results of estimating the panel regressions when two different sets of additional explanatory variables are added as controls.

The first set of controls comprises proxies for domestic monetary and fiscal policies that might be correlated with changes in exchange rates. As a measure of monetary policy, the real shortterm interest rate, $R I R$, was used. ${ }^{6}$ As a measure of fiscal policy, the change in the ratio of the

6 High and variable inflation rates in some of the countries make the nominal interest rate an unreliable measure of monetary tightness. Additionally, the fact that many countries in the sample target some measure of the interest rate (either real or nominal) makes the money supply endogenous and hence also an unreliable measure of monetary policy. We recognise, however, that in countries with controls on nominal interest rates, the real rate may not be an adequate measure of monetary policy. 
Table 2

Fixed effects panel regressions - OLS, controls

Dependent variable: $\Delta \log (Y)$

\begin{tabular}{|l|c|c|c|c|c|c|c|c|}
\hline \multirow{4}{*}{$\Delta$} & \multicolumn{2}{|c|}{ All countries } & \multicolumn{2}{c|}{ Latin America } & \multicolumn{2}{c|}{ Asia } & \multicolumn{2}{c|}{ Industrialised } \\
\cline { 2 - 9 } & Full & Reduced & Full & Reduced & Full & Reduced & Full & Reduced \\
\hline $\log ($ RER $)$ & 0.048 & 0.051 & 0.027 & 0.063 & 0.055 & 0.054 & 0.062 & 0.054 \\
& $(4.29)$ & $(5.17)$ & $(1.27)$ & $(3.70)$ & $(1.89)$ & $(2.16)$ & $(2.89)$ & $(2.83)$ \\
$\Delta \log \left(Y_{-1}\right.$ & -0.014 & 0.001 & -0.015 & 0.006 & 0.002 & -0.008 & 0.012 & 0.025 \\
& $(-1.70)$ & $(0.12)$ & $(-0.92)$ & $(0.47)$ & $(0.11)$ & $(-0.79)$ & $(0.59)$ & $(1.75)$ \\
YGAP-1 & 0.44 & 0.44 & 0.32 & 0.34 & 0.51 & 0.48 & 0.51 & 0.47 \\
& $(9.79)$ & $(10.94)$ & $(3.37)$ & $(3.86)$ & $(5.40)$ & $(5.52)$ & $(8.30)$ & $(8.17)$ \\
$R I R$ & -0.41 & -0.39 & -0.48 & -0.46 & -0.38 & -0.37 & -0.36 & -0.37 \\
& $(-10.25)$ & $(-10.67)$ & $(-5.52)$ & $(-6.01)$ & $(-4.63)$ & $(-5.33)$ & $(-7.29)$ & $(-7.90)$ \\
$\Delta(B U D / G D P)$ & -0.00 & & 0.00 & & -0.00 & & -0.001 & -0.001 \\
& $(-0.66)$ & & $(0.43)$ & & $(-0.64)$ & & $(-1.52)$ & $(-2.73)$ \\
RIRUS & -0.001 & -0.001 & -0.001 & & -0.002 & & -0.000 & \\
& $(-1.65)$ & $(-1.71)$ & $(-1.46)$ & & $(-1.33)$ & & $(-0.66)$ & \\
$\log ($ TOT $)$ & -0.000 & & -0.006 & -0.004 & -0.001 & & 0.000 & \\
$\Delta$ YGAP* & $(-0.69)$ & & $(-2.53)$ & $(-2.33)$ & $(-0.62)$ & & $(0.29)$ & \\
& 0.01 & & 0.04 & & -0.01 & & 0.01 & \\
$\Delta($ KA/GDP $)$ & $(1.23)$ & & $(1.99)$ & & $(-0.69)$ & & $(0.27)$ & \\
& 0.13 & 0.19 & 0.24 & & 0.18 & & 0.13 & 0.20 \\
& $(2.43)$ & $(4.41)$ & $(1.59)$ & & $(1.57)$ & & $(2.46)$ & $(4.36)$ \\
& 0.001 & 0.001 & 0.000 & & 0.001 & & 0.001 & 0.001 \\
& $(1.79)$ & $(2.23)$ & $(0.24)$ & & $(0.86)$ & & $(2.23)$ & $(2.69)$ \\
\hline
\end{tabular}

Note: t-statistics in parentheses.

cyclically adjusted government budget balance to $G D P, \Delta(B U D / G D P)$, was employed. Because cyclically adjusted budget balances are not available for a wide range of countries, we estimated these ourselves as the residual in regressions - country by country - of the actual budget balance on a constant term and the output gap.

The second set of controls employed in the regression for output growth is intended to capture external shocks: real US three-month Treasury bill interest rates, RIRUS, (an important determinant of capital flows); the terms of trade, TOT (export prices/import prices); changes in the weighted output gap of the G-3 countries, $\triangle Y G A P^{*}$; and the change in the ratio of the capital account to GDP, $\Delta(K A / G D P) .^{7}$

For each region represented in Table 2, the results of two equation specifications are shown: estimates of the "full" equation specification, where all the control variables are entered, and

7 The capital account is defined implicitly in the accounting relationship: [current account $]+[$ capital account $]=$ [change in international reserves $]$. 
estimates of "reduced" equations, where control variables with the least statistically significant coefficients have been deleted progressively from the equation. The coefficients on the control variables, while often not statistically significant, are usually of the expected sign. In most of the regressions, increases in domestic and US real interest rates depress output growth while improvements in the terms of trade boost growth. In all of the regressions, increases in the budget surplus - a tightening of fiscal policy - reduce output while increases in the G-3 output gap and in capital inflows raise output.

The introduction of the control variables does not appear to exert a systematic influence on the estimated effect of devaluation on growth. Focusing first on the "full" equations, only in Latin America does the size and significance of the coefficient on the contemporaneous change in the real exchange rate drop substantially; in the "all countries" and Asia regressions, this coefficient remains largely unchanged, and it increases substantially in the "industrialised countries" equation. In the "reduced equations", where insignificant variables have been progressively deleted, the coefficient on the contemporaneous change in the real exchange rate is positive and significant in every case. Hence, with the possible exception of Latin America, the finding of a contractionary effect of devaluation in the short run does not appear to reflect merely a spurious correlation of devaluation with adverse external shocks.

Similarly, introduction of the control variable does not appreciably change the estimated long-run effect of devaluation on output, as measured by the coefficient on the lagged level of the real exchange rate. While this coefficient is measured as negative and nearly significant in the "full" version of the "all countries" regression, this result is obviously far from robust, as deletion of insignificant control variables causes this coefficient to become positive. Moreover, the coefficient on the lagged level of the real exchange rate is positive and nearly significant in the "reduced" version of the equation for the industrialised countries, but very small and highly insignificant in the equations for Latin America and Asia. In sum, introduction of the control variables serves, if anything, to strengthen the view that the real exchange rate exerts no significant effect on output - either contractionary or expansionary - in the long run.

TSLS estimates with controls. Finally, to control for feedbacks from the left-hand side output growth - to the contemporaneous change in the real exchange rate (as discussed in Section 1), the capital account and the budget balance, the "reduced" equations in Table 2 were also estimated with Two-Stage Least Squares (TSLS), as shown in Table 3. ${ }^{8}$ In the "all countries" equation under TSLS, the coefficient on the contemporaneous change in the real exchange rate - that is, the estimated short-term effect of devaluation - drops slightly but remains significant. On the other hand, the significance of this coefficient in the regional regressions drops dramatically. This suggests that an important factor in the observed correlation between the real exchange rate and output growth may be

8 Lagged values of the endogenous variables were used as instruments, along with the other exogenous and predetermined variables in the equations. 
Table 3

Fixed effects panel regressions - TSLS, controls

\begin{tabular}{|c|c|c|c|c|}
\hline & All countries & Latin America & Asia & Industrialised \\
\hline$\Delta \log (\mathrm{RER})$ & $\begin{array}{l}0.043 \\
(3.15)\end{array}$ & $\begin{array}{l}0.031 \\
(1.15)\end{array}$ & $\begin{array}{c}0.092 \\
(1.74)\end{array}$ & $\begin{array}{l}0.038 \\
(1.22)\end{array}$ \\
\hline $\log (\text { RER })_{-1}$ & $\begin{array}{l}-0.003 \\
(-0.46)\end{array}$ & $\begin{array}{l}-0.008 \\
(-0.46)\end{array}$ & $\begin{array}{l}0.004 \\
(0.42)\end{array}$ & $\begin{array}{r}0.022 \\
(1.40)\end{array}$ \\
\hline$\Delta \log (\mathrm{Y})_{-1}$ & $\begin{array}{c}0.45 \\
(10.75)\end{array}$ & $\begin{array}{c}0.29 \\
(3.05)\end{array}$ & $\begin{array}{c}0.50 \\
(6.02)\end{array}$ & $\begin{array}{c}0.47 \\
(7.73)\end{array}$ \\
\hline YGAP $_{-1}$ & $\begin{array}{c}-0.40 \\
(-10.49)\end{array}$ & $\begin{array}{c}-0.43 \\
(-5.24)\end{array}$ & $\begin{array}{c}-0.51 \\
(-6.61)\end{array}$ & $\begin{array}{c}-0.37 \\
(-7.64)\end{array}$ \\
\hline RIR & & & & $\begin{array}{l}-0.001 \\
(-3.22)\end{array}$ \\
\hline$\Delta(\mathrm{BUD} / \mathrm{GDP})$ & $\begin{array}{l}-0.001 \\
(-1.54)\end{array}$ & & & \\
\hline RIRUS & & $\begin{array}{l}-0.004 \\
(-1.61)\end{array}$ & & \\
\hline $\log (\mathrm{TOT})$ & & & & \\
\hline$\Delta \mathrm{YGAP}^{*}$ & $\begin{array}{c}0.20 \\
(4.57)\end{array}$ & & & $\begin{array}{c}0.20 \\
(4.04)\end{array}$ \\
\hline$\Delta(\mathrm{KA} / \mathrm{GDP})$ & $\begin{array}{l}0.000 \\
(0.72)\end{array}$ & & & $\begin{array}{l}0.002 \\
(2.41)\end{array}$ \\
\hline
\end{tabular}

Note: t-statistics in parentheses.

not so much a spurious correlation with other shocks (except, perhaps, in Latin America) but rather feedbacks from output growth to the real exchange rate. Once these feedbacks are controlled through the TSLS procedure, the significance of the estimated contractionary effect of devaluation drops accordingly.

It is not clear why the coefficients on the exchange rate variables are essentially significant in the "all countries" regression but not significant in the regional regressions. A plausible explanation is that devaluation may genuinely be contractionary in the short run, but that this effect is relatively subtle and does not represent a predominant determinant of variations in GDP growth in any one country. This is indicated by the VAR studies surveyed in Section 2, which suggested that the predominant factors explaining variations in GDP were output shocks themselves. Hence, the shortrun contractionary effect of devaluation on output may only be identifiable if consideration is given to a sufficiently large number of countries encompassing a wide variety of trends in real exchange rates and output growth.

Finally, the estimated long-run effect of devaluation on output, as measured by the coefficient on the lagged level of the real exchange rate, remains insignificant in all of the four regressions in Table 3. This further contradicts the possibility that devaluation may be contractionary 
in the long run, although it is also inconsistent with the conventional view that devaluations are expansionary.

\section{Conclusion}

The research described above suggests the following conclusions. First, by employing an error-correction specification that helps to distinguish between dynamics and long-run effects, we can say with some confidence that, regardless of the short-run effects of devaluation, there appears to be no contractionary effect in the long run. This represents good news for policy-makers, since it means that devaluations can be used to achieve balance-of-payments objectives without sacrificing long-run growth targets. On the other hand, our results fail to confirm the conventional or textbook view that devaluations are expansionary in the long run.

Our second main conclusion is that even if devaluations are contractionary in the short run, much of the observed correlation between real exchange rates and output may be attributable to feedbacks from output to the real exchange rate. In equations running OLS and without controls, a significant short-run contractionary effect of devaluation was estimated in all cases. The introduction of controls reduced the estimated significance of this effect only in Latin America and only when all the controls, whether significant or not, were included; this is consistent with a prevalent view that Latin America may be particularly susceptible to shocks that simultaneously depress output and induce devaluation. On the other hand, in the non-Latin America equations, the contractionary impact effect of devaluation remained significant even after the introduction of controls. However, this significance declined substantially after the equations were estimated using TSLS, thereby controlling for feedbacks from output back to the real exchange rate. In sum, once the effects of changes in output on the real exchange rate are eliminated, the measured correlation of output and the real exchange rate weakens substantially.

Our third conclusion - and this is subject to differences of interpretation - is that a shortterm contractionary effect of devaluation on growth genuinely exists, but that it is relatively subtle and difficult to identify, once sources of spurious correlation and reverse causality are controlled for. In the "all countries" regression, the short-run contractionary effect remains significant, even after control variables are added and the equation is estimated using TSLS. We attribute the fact that the estimated effect is not significant in the regional regressions to the possibility that this effect is relatively subtle, accounts for a small portion of the variance in output growth, and hence can only be discerned (using a panel regression approach) in relatively large datasets encompassing a wide range of variation in exchange rates and output. However, we acknowledge that more research in this area may be needed.

Fourth, the results of this research suggest little reason to believe that devaluations are more contractionary in Latin America than in Asia or in the industrialised countries. Once control 
variables are added and the equation is estimated using TSLS, the coefficient on the contemporaneous change in the real exchange rate not only becomes insignificant in the Latin America regression, as noted above, but its value is estimated to be lower than that for both Asia and the industrialised countries.

Finally, the literature on contractionary devaluation has generally focused on developing countries, with the implicit assumption that the effects of devaluations in industrialised countries are more likely to adhere to the conventional textbook model. However, if the results in Table 3 are taken at face value, they suggest that, compared with developing countries, devaluations in industrialised countries are about as contractionary in the short run and more contractionary in the long run. Given the lack of significance of the coefficients in question, as well as their high sensitivity to changes in equation specification, it probably would be inappropriate to take these results too literally. Nevertheless, the results presented in this paper do not provide support for the view that contractionary devaluation is limited to the developing countries, while expansionary devaluation prevails in the industrialised countries. 


\section{Data appendix}

Y Real gross domestic product.

YGAP Log of output gap (actual/potential); potential GDP calculated by fitting HP filter to actual real GDP.

RER Real multilateral effective exchange rate (in terms of relative consumer prices), end of year (BIS calculation).

RIR Real short-term interest rate. Annual average of monthly short-term interest rates, deflated by contemporaneous monthly changes in consumer prices.

BUD/GDP Cyclically adjusted government budget balance as a percentage of GDP.

RIRUS Real short-term interest rate for the United States (calculated as described above, based on three-month Treasury bill interest rate).

TOT Terms of trade (export unit value divided by import unit value).

YGAP* Log of output gap for the G-3 countries (Germany, Japan and the United States). Average of countries calculated using weights based on 1990 GDP and PPP exchange rates.

KA/GDP Capital account as a percentage of GDP. The capital account is calculated as the difference between the current account and the change in reserves.

Sources: IMF International Financial Statistics, IMF Balance-of-Payments Statistics, OECD Economic Outlook, BIS and national data. 


\section{References}

Agenor, Pierre-Richard (1991): "Output, Devaluation and the Real Exchange Rate in Developing Countries". Weltwirtschaftliches Archiv, vol. 127, pp. 18-41.

Calvo, Guillermo and Carlos A. Vegh (1993): "Exchange Rate Based Stabilization under Imperfect Credibility", in Helmut Frisch and Andreas Worgotter (eds.), Open Economy Macroeconomics, London: MacMillan, pp. 3-28.

Calvo, Guillermo, Carmen Reinhart and Carlos A. Vegh (1994): "Targeting the Real Exchange Rate: Theory and Evidence". IMF Working Paper no. 94/22.

Copelman, Martina and Alejandro M. Werner (1996): "The Monetary Transmission Mechanism in Mexico". Working paper, Federal Reserve Board.

Diaz-Alejandro, Carlos F. (1963): "A Note on the Impact of Devaluation and the Redistributative Effects". Journal of Political Economy, vol. 71, pp. 577-80.

Dornbusch, Rudiger (1980): Open Economy Macroeconomics, New York: Basic Books.

Dornbusch, Rudiger and Alejandro Werner (1994): "Mexico: Stabilization, Reform and No Growth". Brookings Papers on Economic Activity, vol. 1, pp. 253-315.

Edwards, Sebastian (1989): "Real Exchange Rates, Devaluation, and Adjustment". Cambridge, Massachusetts: MIT Press.

Hoffmaister, Alexander W. and Carlos A. Vegh (1996): "Disinflation and the RecessionNow-Versus-Recession-Later Hypothesis: Evidence from Uruguay". IMF Staff Papers, vol. 43, pp. 355-394.

Kamin, Steven B. (1996): "Exchange Rates and Inflation in Exchange-Rate Based Stabilizations: An Empirical Examination". International Finance Discussion Paper No. 554, Board of Governors of the Federal Reserve System, Washington, D.C.

Kamin, Steven B. and John H. Rogers (1997): "Output and the Real Exchange Rate in Developing Countries: An Application to Mexico". International Finance Discussion Paper No. 580, Board of Governors of the Federal Reserve System, Washington, D.C.

Kiguel, Miguel and Nissan Liviatan (1992): "The Business Cycle Associated with Exchange Rate Based Stabilization". World Bank Economic Review, vol. 6, pp 279-305.

Krugman, Paul and Lance Taylor (1978): "Contractionary Effects of Devaluation". Journal of International Economics, vol. 8, pp. 445-56.

Lizondo, Saul and Peter J. Montiel (1989): "Contractionary Devaluation in Developing Countries: An Analytical Overview". IMF Staff Papers, vol. 36, pp. 182-227.

Mendoza, Enrique G. and Martin Uribe (1996): "The Syndrome of Exchange-Rate-Based Stabilizations and the Uncertain Duration of Currency Pegs". International Finance Discussion Paper No. 548, Board of Governors of the Federal Reserve System, Washington, D.C.

Morley, Samuel A. (1992): "On the Effect of Devaluation During Stabilization Programs in LDCs". Review of Economics and Statistics, LXXIV, pp 21-7. 
Rodriguez, Gabriel H. and Guillermo Diaz Gazani (1995): "Fluctuaciones Macroeconomicas en la Economia Peruana". Working paper, Banco Central de Reserva del Peru.

Rogers, John H. and Ping Wang (1995): "Output, Inflation and Stabilization in a Small Open Economy: Evidence from Mexico". Journal of Development Economics, vol. 46, pp. 271-93.

Roldos, Jorge E. (1995): "Supply-Side Effects of Disinflation Programs". IMF Staff Papers, vol. 42 , pp. 158-83.

Santaella, Julio and Abraham E. Vela (1996): "The 1987 Mexican Disinflation Program: An Exchange-Rate-Based Stabilization?" IMF Working Paper no. 96/24.

Uribe, Martin (1995): "Exchange-Rate-Based Inflation Stabilization: The Initial Real Effects of Credible Plans". International Finance Discussion Paper No. 503, Board of Governors of the Federal Reserve System, Washington, D.C. 



\section{Recent BIS Working Papers}

No.

32

December 1995

33

January 1996

34

January 1996

35

July 1996

36

August 1996

37

September 1996

38

October 1996

39

January 1997

40

March 1997

41

May 1997

42

June 1997

43

July 1997

44

July 1997

45

August 1997

46

September 1997

47

September 1997
Title

Author

The anatomy of the bond market turbulence of 1994

Derivatives and asset price volatility: a test using variance ratios

Monetary policy and the behaviour of interest rates: are long rates excessively volatile?

Varieties of monetary policy operating procedures: balancing monetary objectives with market efficiency

Estimation of speculative attack models: Mexico yet again

Does the term structure predict recessions?

The international evidence

International agreements in the area of banking and finance: accomplishments and outstanding issues

Banking system failures in developing and transition countries: diagnosis and prediction

Monetary policy operating procedures industrial countries

The euro and European financial markets

Measuring monetary policy shocks in France, Germany and Italy: the role of the exchange rate

Exchange rate regimes and the expectations hypothesis of the term structure

Is there excess comovement of bond yields between countries?

A multi-country comparison of the linkages between inflation and exchange rate competitiveness

Global asset allocation in fixed income markets

Financial asset prices and monetary policy: theory and evidence
Srichander

Ramaswamy

Claudio E.V. Borio

Robert N. McCauley

Benjamin H. Cohen

Stefan Gerlach

Joseph Bisignano

William R. Melick

Henri Bernard and Stefan Gerlach

William R. White

Patrick Honohan

Claudio E. V. Borio

Robert N. McCauley and William R. White

Frank Smets

Stefan Gerlach and Frank Smets

Gregory D. Sutton

Steven B. Kamin

Frank Smets 